\title{
Capital Flight and the Economic Growth: Evidence from Nigeria
}

\section{Adedoyin Isola Lawal'; ${ }^{1}$ Promise Kelechi Kazi²; Olabode Johnson Adeoti ${ }^{3}$; Godswill Osagie Osuma ${ }^{4}$; Sunday Akinmulegun ${ }^{5}$; Bamidele Ilo ${ }^{6}$}

\author{
${ }^{1,2}$ Accounting and Finance Department, Landmark University \\ PMB 1001, Omu Aran, Nigeria \\ ${ }^{3}$ Business Administration Department, University of Ilorin \\ PMB 1515, Ilorin, Nigeria \\ ${ }^{4}$ Banking and Finance Department, Covenant University \\ 10 Idiroko Rd, Ota, Nigeria \\ ${ }^{5}$ Banking and Finance Department, Adekunle Ajasin University \\ 23482, Akungba, Nigeria \\ ${ }^{6}$ Accounting, Banking and Finance Department, Olabisi Onabanjo University \\ PMB 115, Ago Iwoye, Nigeria \\ 1'lawal.adedoyin@lmu.edu.ng; ${ }^{1}$ l.adedoyin@yahoo.com, ${ }^{2}$ kazi.promise@1mu.edu.ng; ${ }^{3}$ adeoti.olabode@unilorin.edu.ng; \\ ${ }^{4}$ osuma.osagie@covenantuniversity.edu.ng; ${ }^{5}$ akinmuleguns@yahoo.com; ${ }^{6}$ ilobami@yahoo.com
}

Received: $15^{\text {th }}$ March 2017/ Revised: $6^{\text {th }}$ April 2017/ Accepted: $8^{\text {th }}$ May 2017

How to Cite: : Lawal, A. I, Kazi, P. K., Adeoti, O. J., Osuma, G. O., Akinmulegun, S., \& Ilo, B. (2017). Capital Flight and the Economic Growth: Evidence from Nigeria. Binus Business Review, 8(2), 125-132.

http://dx.doi.org/10.21512/bbr.v8i2.2090

\begin{abstract}
This research examined the impact of capital flight and its determinants on the Nigerian economy using the Autoregressive Distributed Lag (ARDL) model to analyze data source from the period of 1981 to 2015. The variables included current account balance, capital flight, foreign direct investments, foreign reserve, inflation rate, external debt, and the real gross domestic product. It was to examine the existence of a long run relationship among the variables studied. The result indicates that capital flight has a negative impact on the economic growth of Nigeria. Therefore, the government needs to implement policies that will promote domestic investment and discourage capital flight from Nigeria.
\end{abstract}

Keywords: economic growth, capital flight, Nigerian economy, Autoregressive Distributed Lag model

\section{INTRODUCTION}

Currently, successive governments in Nigeria have continued to campaign for inflows of capital to Nigeria as a way of boosting economic growth through Foreign Direct Investment (FDI) or Direct Portfolio Investment. This is premised on the need to attract adequate funding required to complement the current limited financial position to financial growth. The current trend in globalization allowing easier flow of money across boarders has awakened researchers' interest in the impact of capital flight in the domestic economy.
Adetiloye (2011) said that a total of $\$ 107$ billion was reported to have flown out of Nigeria between 1970 to 2001 . This fact is alarming and has arisen the interest among researchers to the impact of capital flight in the domestic economy. Though a vast literature existing on the ongoing debate about the link between capital flight and domestic investment, little has been done regarding the specific-country analysis like Nigeria.

Capital flight discussion remains as an inconclusive debate among researchers. The issues relating to measurement, concept, effects consequences and benefit remain object of hot debate 
for Pastor (1990); Baker (2000); Ayogu and Abgor (2014); Beja (2007); Boyce (1992); Gusarova (2009); De Boyrie (2011); Dickey and Fuller (1981); Umoru (2013); King (2015); Ndikumana and Boyce (2008); Vanguard (2010); Hermes, Lensink, and Murinde (2002); Jonathan (2004); Kolapo and Oke (2012); and Usman and Arene (2014).

Ajayi (2012) and Pastor (1989) observed three theories as the keys to capital flight research. There were the investment diversion theory, Debt - driven capital flight theory that was called as debt-overhang theory, and Tax - depressing theory and Austerity generating theory. The investment diversion theory identified instability in the macroeconomic and political systems in developing economies and seen better investment alternatives outside homeland as the key driver of capital flight. It explained that corrupt leaders of developing economies often siphoned scarce capital resources in their homeland economy to countries that offered alternative investment atmosphere. Then, the debt driven capital flight theory was an improvement on the investment diversion theory. It added that huge amount of external debt in homeland often induced residents to move their investible funds to foreign lands. Moreover, the taxdepressing theory was premised on the fact that capital flight was largely caused by the high increase in tax in the domestic economy.

Hoa and Lin (2016) conducted a research in Indochina, namely Cambodia, Laos, and Vietnam. The objective was to examine the role of economic, instructional and political factors in attracting Foreign Direct Investment (FDI) inflows. Hence, a sample period of 16 years from 1996 to 2012 was applied in the research, whereas panel unit root test and Random effects tests were used in obtaining the empirical analysis. From the empirical results, market size, government effectiveness, the rule of law, and political stability appeared to have the positive relationship with inward FDI.

Moreover, Liew et al. (2016) empirically examined the macroeconomic elements of capital flight in Malaysia. Those were FDI, stock market, external debt, and political risk. The research utilized ADF and PP unit root tests, KPSS stationary test, bounds test for co-integration, and the ARDL approach. Other than that, World Bank (1985) measurement was used to determine the aspects that influenced capital flight in Malaysia. The empirical findings revealed that FDI, the stock market, external debt were negatively related to capital flight, while political risk had the positive association with capital flight.

Choong et al. (2010) investigated the effect of debts and economic growth in Malaysia for an empirical period of 1970 to 2006 . They also applied different types of debts other than external debt especially long-term debt, short-term debt, total debt service, and multilateral debt. The empirical results illustrated that an increase in the level of external debt had an impact on the economic performance of countries with better financial systems had greater success in absorbing private capital inflows rather than capital outflows. In short, the decrease in the external debt eventually drew investors to invest in a country due to better economic performance.

Meanwhile, Brada et al. (2011) estimated capital flight from seven countries of the Commonwealth of the Independent States such as Armenia, Azerbaijian, Belarus, Kazakhstan, Moldova, the Russian Federation, and Ukraine. Data from 1995 to 2005 and OLS panel regression were adopted. They discovered political factors affecting the expected return on domestic investments could be seen from the country's polity score variable. Moreover, a more democratic regime provided investors with protection through the rule of law and limits on predation. In other words, the outflow of capital could be lessened as the political risk is low because investors regarded the country as politically stable for investment activities. Thus, political risk and capital flight were positively related.

Similarly, Lan et al. (2010) conducted the research in China using yearly data span from 1992 to 2007, and ARDL bounds testing procedure. They discovered that changes in the domestic economy and political environment would affect capital flow. These included political instability such as social disorder and change in economic policies. Cheung and Qian (2010) studied the empirical determinants of China's capital flow by utilizing quarterly data from 1999 (Q1) to 2008 (Q2). The empirical result depicted that outflow of capital could be seen as a result of distortions due to the political structure. Therefore, it was proven that when the country was politically safer, it would help in attracting and boosting the confidence of investor to invest.

Moreover, Liew et al. (2016) used the residual approach by World Bank to assess capital flight in Malaysia. The data were annual data ranging from 1975 to 2013. The results showed there was an existence of a positive and significant relationship between political risk and outflow of capital. To sum up, this meant the increase in political risk was escorted to expansion in the capital outflow. On the other hand, Mukhtar et al. (2014) aimed to explore different elements influencing FDI in developing countries such as Pakistan, India, and Bangladesh. The empirical study illustrated that GDP growth rate, inflation rate, tax rate, exchange rate, openness, infrastructure, good governance, and political risk could significantly stimulate the flow of FDI in the developing countries. In addition, this affected the decision of investors to invest in a country.

Then, Kueh et al. (2010) used the ADF unit root test, Johansen and Juselius cointegration test and Granger causality test based on error correction model, and inspected the association between direct investment abroad of Singapore and few of the determinants under the research. Throughout the analysis from 1975 to 2007, the empirical results showed that exchange rate has the impact on the abroad investment in Singapore. The reason was the stability and flexibility of the economy towards external economic shocks that reinforced the currency 
of Singapore. Consequently, it encouraged foreign investment by domestic firms in the long-run and led to outward FDI.

Next, Gunter (2017) calibrated the impact of corruption and family effects on capital flight in economic growth of nexus in China based on data from 1984 to 2014. The research used both the Cuddington's balance of payments and residual measures to investigate this relationship by adjusting and reflecting the legitimate assets of the Chinese banking industry, misinvoicing of China's trade with its major trading partners, exchange rates, and the weakness of the official debt data among others. The research observed that capital control had little or no long term impact on the volume of capital especially the capital flight route in Hong Kong. The research also observed that corruption, transaction costs, migration facilitation process were the prime driver of capital flight from mainland China.

From a panel of 29 African economies, Efobi and Asongu (2016) analyzed the effects of terrorism on the capital flight based on data from 1987 to 2008 using the Generalized Method Moment (GMM) with Forward Orthogonal Deviations (FOD) and Quantile regression (QR). In the results, GMM showed that domestic, transnational unclear and total terrorism consistently increased capital flight. Meanwhile, QR showed that except transnational terrorism which showed the positive effect on capital flight at about $0,90^{\text {th }}$ quintile, terrorism dynamics affected capital flight in low quintiles of the capital flight distribution.

In another development, Cheung, Steinkamp, and Westermann (2016) studied China's illicit capital flow behavior within the context of interest rate disparity using 2007 as the determinant year. They observed that China's capital flight exhibited a weakened response in the post- 2007 period. This behavior was influenced by quantitative easing and other factors such as exchange rate variability, capital control policy, and trade frictions. They concluded that China's capital flight patterns and its determinants were largely influenced by critical events.

Next, Kunieda, Okada, and Shibata (2014) conducted both theoretical and empirical methods to investigate the effect of government corruption, and capital account liberalization on economic growth with keen interest on the impact of capital flight for a panel data from 109 economies. The results obtained showed that corruption induced capital flight with great consequences on economic growth.

Carp (2014) observed that in current economic and financial crisis, financial globalization could cause a rise in capital flow volatility with a disturbing effect on economic growth and development for economies in Central and Eastern European Countries (CEECs). The research recommended a careful movement towards financial liberalization to mitigate against capital.

In the related development, Brada, Kutan, and Vuksic (2013) analyzed the capital flight from 10 Central and Eastern countries based on data from
1996 to 2009. They also described that capital flight from transition economies was largely influenced by interest rates, investors sentiment, and the ease associated with movement of funds across borders. The result showed that domestic credit expansion was the key to influence capital flight and financial liberalization had fueled capital flight by increasing fund movement and reducing its cost. In addition, Pyun and An (2016) calibrated the effect of financial integration to capital flight economic growth nexus based on panel data from 58 countries in 2001 to 2013. It showed that global financial crisis and the highlevel cointegration among global economies with the US as the arrow head influenced the impact of capital flight responses, business cycle co-movements, local fundamental factors, investment channels as factors that influenced capital flight.

Yalta and Yalta (2012) used a panel causality approach to examine the impact of financial development and liberalization on the capital flight by focusing on the unrecorded accumulation of foreign assets by the private sector. It was based on data from 21 emerging economies for the period of 1980 to 2004 . The research observed the existence of lagged values of capital flight with a self-reinforcing characteristic. It was noted that financial liberalization policies had little or no effect in reducing capital flight.

Anaya, Hachula, and Offermanns (2017) used a structural global VAR model to analyze the impact of US unconventional monetary policy shock as defined by changes in the central balance sheet. It was on the financial and economic conditions of emerging market economies. It also investigated whether or not international capital flight flows were an important channel of shock transmission. They observed that an expansionary policy significantly increased portfolio flows from the US to emerging economies for the periods studied. This was accompanied by a persistence movement in real and financial variables in the receiving emerging economies.

In the previous researches, it has examined the effect of capital flight, the consequences, major players in the development of nations including Nigeria. Those have also shown several responsible factors for capital flight. Then, this research fills the gap by examining the impact of capital flight on domestic economic growth in Nigeria. The results of the research will help policy makers in knowing that the impact of capital flight on the nation's economy and what policy instruments are to prevent further escalation of capital flight in Nigeria.

\section{METHODS}

Data are quarterly data from 1981 to 2015 from Central Bank of Nigeria Statistical Bulletin (various issues). Preliminary tests to know the normality and stationarity of the data are conducted through JarqueBera, Skewness, Kurtosis tests, and the unit root test. The results of the Jarque-Bera, Skewness and Kurtosis 
tests show that the data are normal. Then, this informs the choice of the Autoregressive Distributed Lag (ARDL) model. The preference of the ARDL over other estimating techniques have been documented in the previous researches (see also Ozturk \& Acarava, 2010; Bekhet \& Matar, 2013; Marashdeh, 2005; Odhiambo, 2010; Babajide et al., 2016a, 2016b, 2015; Babajide \& Lawal, 2016; Lawal, Somoye, \& Babajide, 2016; Lawal, Babalola, Otekunrin, \& Adeoti, 2016; Isola, Oluwafunke, Victor, \& Asaleye, 2016; Lawal, Nwanji, Asaleye, \& Ahmed, 2016).

The model for the research is based on the theoretical and previous researchers, and the researchers adopt the residual approach to capital flight as formulated by World Bank (1985) and Erbe (1985). This is because it includes macroeconomic variables that determine the economic growth in Nigeria. The variables include dependent variable like Gross Domestic Product (GDP), and independent variables such as Foreign Direct Investment (FDI), Foreign Reserve (FR), Current Account Balance (CAB), and External Debt (EXTDEBT). The model is specified in Equation (1). Then, it transforms this functional representation of growth equation in the linear equation as seen in Equation (2).

$R G D P=f(C A B, F R, E X T D E B T, F D I) \ldots \ldots \ldots$

$R G D P=\beta_{0}+\beta_{1} F R-\beta_{2} C A B+\beta_{3} E X T D E B T+\beta_{4} F D I$

$+\mu t$

Where the descriptions are:

$\mu \mathrm{t}=$ Error term

$\beta_{0}=$ Intercept parameter of the model

$\beta_{1}-\beta_{4}=$ Coefficient of the independent variables

The ARDL estimate is stated as:

$$
\begin{aligned}
& \Delta \operatorname{InRGDP}=\beta_{01}+\sum_{i=1}^{n 1} \beta_{11} \Delta \operatorname{In} R G D P_{i-t}+\sum_{i=0}^{n 2} \\
& \beta_{12} \Delta \operatorname{In} F R_{i-t}+\sum_{i=0}^{n 3} \beta_{13} \Delta \mathrm{CAB}_{i-t}+\sum_{i=0}^{n 4} \\
& \Delta \mathrm{EXTDEBT}_{t-i}++\sum_{i=0}^{n 4} \beta_{14} \Delta \mathrm{FDI}+\phi_{11} \operatorname{InRGDP}_{t-1} \\
& +\phi_{12} \operatorname{In} E X T D E B T_{t-1}+\phi_{13} \mathrm{FX}_{t-1}+\phi_{14} \mathrm{CAB}_{t-1}++\phi_{14} \\
& \mathrm{FDI}_{t-1}+\varepsilon_{t 1}
\end{aligned}
$$

Meanwhile, Error Correction Model (ECM) representation of the ARDL approach is as follows:

$$
\Delta \operatorname{InRGDP}_{\mathrm{t}}=\beta_{01}+\sum_{i=1}^{n 1} \beta_{11} \Delta \operatorname{In} R G D P_{i-t}+
$$

$$
\begin{aligned}
& \Delta \mathrm{InFR}_{\mathrm{t}-\mathrm{i}}+\sum_{i=0}^{n 3} \beta_{13} \quad \Delta \mathrm{CAB}_{\mathrm{t}-\mathrm{i}}+\sum_{i=0}^{n 4} \beta_{14}
\end{aligned}
$$

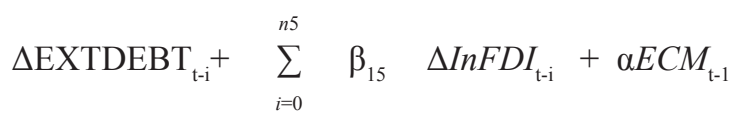

Where, $\beta_{11}-\beta_{15}$ represent the short term coefficients. $\phi 11-\phi 15$ represent the long run coefficients, and and $\mathrm{n} 1 \ldots \mathrm{n} 5$ are the lag strength.

\section{RESULTS AND DISCUSSIONS}

The result in Table 1 indicates that the mean of GDP is $1,8 \mathrm{E}+11$. Then, the coefficient of skewness and kurtosis are 1,79 and 4,85 respectively. It indicates that the GDP is positively skewed and the distribution is leptokurtic (distribution with kurtosis is greater than 3 ). In other words, the degree of peakness is high. It also means that the degree of peakness is not normal. The excess kurtosis can be calculated by kurtosis minus 3 that is $4,85-3=1,85$. The result is consistent with the Jarque-Bera test which has a calculated value of approximately 23 and an asymptotical probability of 0,000010 which is less than $1 \%$. Therefore, GDP is not normal which leads to the rejection of the distribution.

Meanwhile, external debt and capital flight are negatively skewed, and the distribution is platykurtic (distribution with kurtosis that is less than 3). Current account balance and foreign direct investment are positively skewed, and the distribution is leptokurtic (distribution with kurtosis that is greater than 3). The Foreign reserve is positively skewed, but the distribution is platykurtic. In conclusion, it can be said that the variables are not normally distributed.

For unit root test in Table 2, the test for stationarity shows that all variables except FDI are non-stationary. Therefore, there is a need for the first difference which shows that all variables are stationary at first difference.

With the LRGDP as the dependent variable as shown in Table 3, it shows that a long run relationship exists between the variables using ARDL model. From the result, it can be deduced that in the long run, the relationship between each variable and the RGDP is positive except for exchange rate. Furthermore, a significant relationship exists between RGDP, CAB FR, EXTDEBT, FDI, and KF. In the short run, a significant relationship exists between the RGDP and all the policy instruments except for FDI and CAB. Moreover, the relationship between all the variables and RGDP is positive except for money supply and exchange rate. The ECMt-1 indicates a negative sign as expected by theory and is significant. This implies that the speed of adjustment is back from the short term disequilibrium to the long-term equilibrium. 
Table 1 Descriptive Statistics

\begin{tabular}{llllll}
\hline & GDP & CAB & FR & FDI & EXTDEBT \\
\hline Mean & $1,18 \mathrm{E}+11$ & $6,63 \mathrm{E}+09$ & $1,58 \mathrm{E}+10$ & $-1,88 \mathrm{E}+09$ & $2,50 \mathrm{E}+10$ \\
Std. Dev. & $1,56 \mathrm{E}+11$ & $1,17 \mathrm{E}+10$ & $1,84 \mathrm{E}+10$ & $2,68 \mathrm{E}+09$ & $8,44 \mathrm{E}+09$ \\
Skewness & 1,790026 & 1,302646 & 0,959486 & 0,862971 & $-0,320425$ \\
Kurtosis & 4,847441 & 3,765532 & 2,233290 & 7,135295 & 1,838713 \\
Jarque-bera & 22,99223 & 10,44591 & 6,049586 & 28,44602 & 2,492308 \\
Prob & 0,000010 & 0,005391 & 0,048568 & 0,000001 & 0,287609 \\
Observations & 34 & 34 & 34 & 34 & 34 \\
\hline
\end{tabular}

(Source: Authors' computation (2016), using E-Views 9.5)

Table 2 First Difference

\begin{tabular}{cccccc}
\hline VARIABLES & $\begin{array}{c}\text { ADF TEST } \\
\text { STATISTICS }\end{array}$ & $\begin{array}{c}\text { ORDER OF } \\
\text { INTEGRATION }\end{array}$ & PP TEST & $\begin{array}{c}\text { ORDER OF } \\
\text { INTEGRATION }\end{array}$ & REMARK \\
\hline LRGDP & $-5,298139$ & $\mathrm{I}(1)$ & $-5,292232$ & $\mathrm{I}(1)$ & STATIONARY \\
CAB & 4,024972 & $\mathrm{I}(1)$ & $-3,614121$ & $\mathrm{I}(1)$ & STATIONARY \\
LFR & $-5,194393$ & $\mathrm{I}(1)$ & $-6,679733$ & $\mathrm{I}(1)$ & STATIONARY \\
LEXTDEBT & $-4,482059$ & $\mathrm{I}(1)$ & $-4,368239$ & $\mathrm{I}(1)$ & STATIONARY \\
FDI & $-3,954336$ & $\mathrm{I}(1)$ & $-29,61881$ & $\mathrm{I}(1)$ & STATIONARY \\
\hline
\end{tabular}

(Source: Authors' computation (2016), extracted from Eviews 9.5)

Table 3 Estimated Long Run and Short Run Coefficient Using ARDL Model Selected Based on SBC

\begin{tabular}{|c|c|c|c|c|c|}
\hline \multicolumn{3}{|c|}{ Long run Coefficients } & \multicolumn{3}{|c|}{ Short run Coefficients } \\
\hline Regressors & Coefficients & T. Ration & Regressors & Coefficients & T. Ration \\
\hline$\alpha 0$ & $-0,3684$ & $-1,0735$ & $\Delta \alpha 0$ & $-0,0944$ & 0,1079 \\
\hline LRGDP & 0,3979 & $3,0922 *$ & $\Delta \mathrm{L} \mathrm{RGDP}$ & 0,1020 & $2,7988^{*}$ \\
\hline CAB & 1,4353 & $6,1912 *$ & $\triangle \mathrm{L} \mathrm{CAB}$ & 0,3679 & 4,4233 \\
\hline LFR & 0,7502 & $3,5918 * *$ & $\Delta \mathrm{L} \mathrm{FR}$ & 0,1923 & 3,0198 \\
\hline LEXTDEBT & 1,4782 & $1,8959 * *$ & $\triangle \mathrm{L}$ EXTDEBT & $-0,4315$ & $-1,7198 *$ \\
\hline FDI & 2,5054 & $-2,4879 * * *$ & $\Delta \mathrm{L} \mathrm{FDI}$ & 0,2066 & $0,66953 * *$ \\
\hline & & & ECM t-1 & $-0,3728$ & $-4,5325 * *$ \\
\hline
\end{tabular}

$*, * *, * * *$ represent $1 \% ; 5 \% ; 10 \%$ respectively

Dependent variable: LRGDP

(Source: Authors' computation, 2016)

In order to determine the stability of the estimated ARDL model within the context of the coefficients of the long run and the short run relating to the link between capital flights and its causes, the researachers use the Cumulative Sum of Recursive Residuals (CUSUM) and the Cumulative Sum of Squares (CUSUMQ). The rules says if the plots lie within the 5\% range of significance level, the null hypothesis implies that the coefficients in the Error Correction Models (ECM) are stable and cannot be rejected. Thus, the null hypothesis of the constancy of the coefficients can be rejected (Bahmani-Oskooee \& $\mathrm{Ng}, 2002$ ).

From the CUSUM test in Figure 1, the dependent variable is stable because the plot of the CUSUM is within the range of 5\% of significance within the two straight lines. Thus, the null hypothesis which states the error correction model is stable and cannot be rejected (Bahmani-Oskooee \& Ng, 2002). If either of the lines is crossed, the null hypothesis of the coefficient consistency can be rejected at $5 \%$ of significance.

For the long run relationship as seen in Figure 2 and Figure 3, the model is unrestricted with intercept and no trend. Then, the F-statistics is 1,722235. From Table 3, the lower bound value is 0,290523 , and the upper bound value is $-5,68 \mathrm{E}-11$. The F-statistics of the upper bound is greater than the lower bound. Thus, the researchers reject the null hypothesis. From the results of the ARDL and error correction model, it can be seen that co-integration exists among all the variables. This implies that there is a significant relationship between GDP and the macroeconomic variables, so the null hypothesis is rejected. 


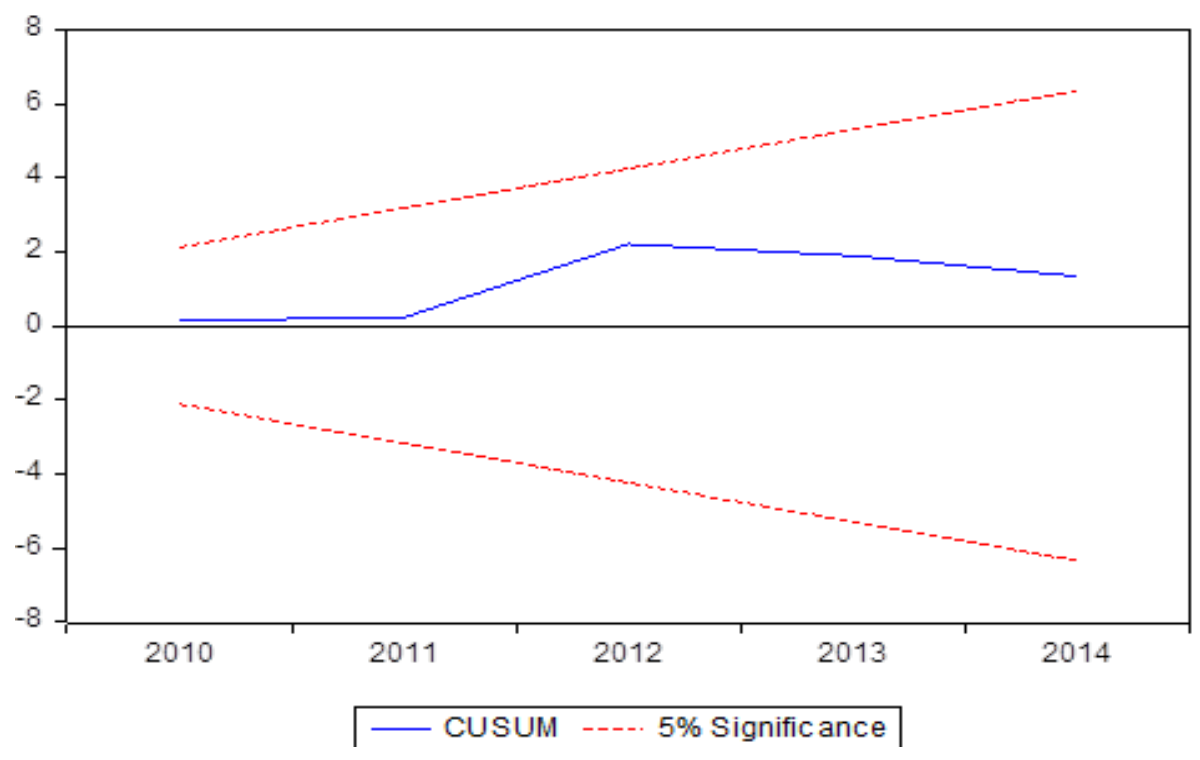

Figure 1 Plot of the CUSUM Statistics Test

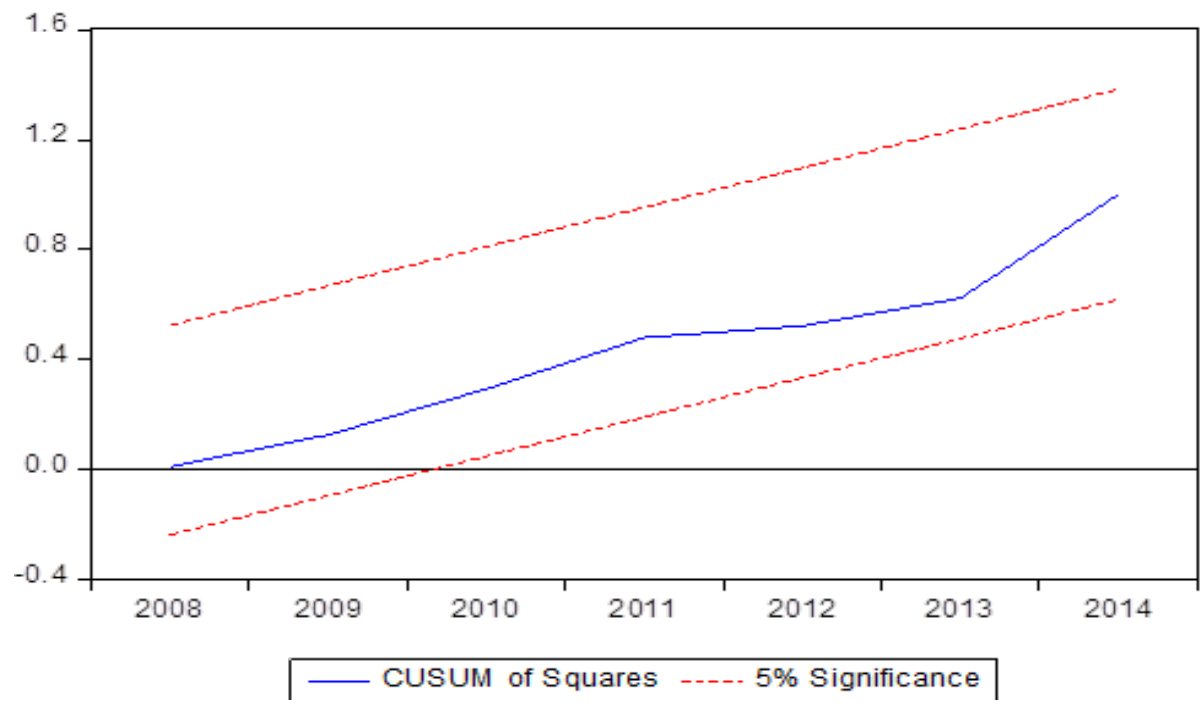

Figure 2 Plot of the CUSUM of Squares Test

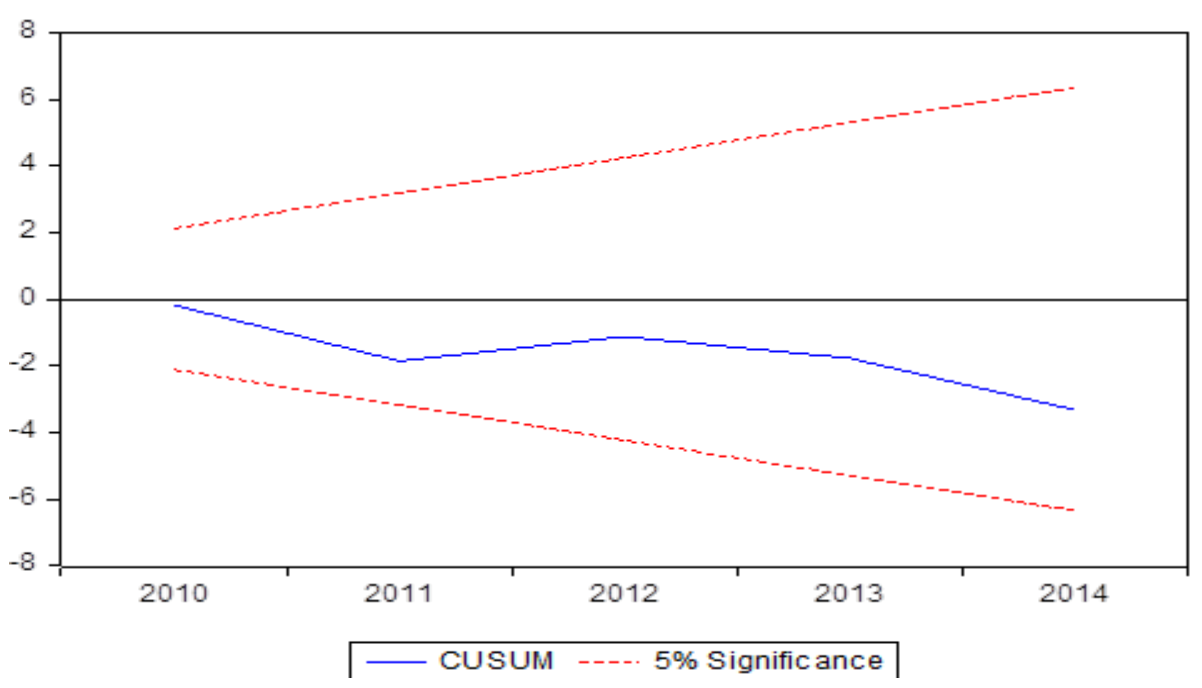

Figure 3 Plot of CUSUMQ Statistics Test 
From the findings, it can be observed that some of the existing researches by Ajayi (2012), and Ifedayo and Olawale (2015) state that capital flight affects the economic growth in Nigeria both in the long and short runs negatively. A negative impact also exists from external debt in capital flight. Furthermore, the econometric analysis reveals that Nigeria external debt negatively exerts the capital flight in Nigeria to the magnitude. For every new dollar of external borrowing, at least sixty cents exit Nigeria as the capital in the same period. This is reflected in the year to year correlation between external borrowing and capital flight. Thus, appropriate debt management practice is the key to tackle capital debt crisis in Nigeria (see also Ndikumana et al., 2015).

\section{CONCLUSIONS}

This article investigates the effects of capital flight and its determinants on the Nigerian economy by using ARDL model to explore quarterly data from 1981 to 2015. The variables used include current account balance, capital flight, foreign direct investments, foreign reserve, inflation rate, external debt, and the real gross domestic product. The focus of the study centers around whether a long run relationship exists among the variables mentioned or not. From the results, it shows that capital flight has a negative impact on the economic growth of Nigeria. Thus, it requires the government to adopt and implement policies that will promote and stimulate domestic investment, and discourage capital flight from Nigeria.

The research recommends that government should provide an attractive and conducive environment for investors who will enable them to stay back in Nigeria and invest more. It is more important to make the domestic economy more attractive for the investors by creating a wider menu of domestic financial assets on which domestic capital can be assessed and invested at a lower rate compared to foreign financial instruments. A typical example is the United Kingdom environment, where a Nigerian will prefer staying there rather than coming to their home country to invest. Government officials should also be responsible for their various duties. They should put their duties ahead of their personal advancement. This helps the economy to experience an improvement because such fund will be used for the right project such as the opening of new lucrative sectors as well as the generation of power.

\section{REFERENCES}

Adetiloye, K. A. (2011). Capital flight and investment in Nigeria in the era of financial globalization (1970 - 2007) (Unpublished Ph.D. Thesis). Nigeria: Covenant University.

Ajayi L. B. (2012). Capital flight and Nigeria economic growth. Asian Journal of Finance and Accounting, $4(2), 277-289$.
Anaya, P., Hachula, M., \& Offermanns, C. J. (2017). Spillovers of US unconventional monetary policy to emerging markets: The role of capital flows. Journal of International Money and Finance, 73, 275-295.

Ayogu, M., \& Abgor, J. (2014). Illicit financial flows and stolen asset value recovery. In S. I. Ajayi \& L. Ndikumana (Eds.), Capital flight from Africa: Causes, effects and policy issues. Oxford: Oxford University Press

Babajide A. A., Lawal A. I., \& Somoye R. O. C. (2016a). Stock market volatility: Does our fundamentals matter? Economic Studies Journal, 25(3), 33- 42.

Babajide, A. A., \& Lawal, A. I. (2016). Macroeconomic behaviour and FDI inflows in Nigeria: An application of the ARDL model. British Journal of Economics, Finance and Management Sciences, 11(1), 84-107.

Babajide, A. A., Lawal, A. I., \& Somoye, R. O. C. (2015). Monetary policy dynamics and the stock market movements: Empirical evidence from Nigeria. Journal of Applied Economic Sciences, 10(8), 38.

Babajide, A. A., Lawal, A. I., \& Somoye, R. O. C. (2016b): Stock market response to economic growth and interest rate volatility: Evidence from Nigeria. International Journal of Economics and Financial Issues, 6(1), 354-360.

Bahmani-Oskooee, M., \& Ng, R. C. W. (2002). Long-run demand for money in Hong Kong: An application of the ARDL model. International journal of business and economics, 1(2), 147-155.

Baker, R. W. (2000). Illegal flight capital: Dangers for global stability. International Politik, 6, 12- 24.

Beja, E. L. (2007). Capital flight and economic performance: Growth projection for Philippines. Munich Personal RePEc Archive, Paper No. 4885.

Bekhet, H. A., \& Matar, A. (2013). Co-integration and causality analysis between stock market prices and their determinates in Jordan. Economic Modelling, 35, 508-514.

Boyce, J. K. (1992). The revolving door? External debt and capital flight: A Philippine case study. World Development, 20(3), 335-349.

Brada, J. C., Kutan, A. M., \& Vukšić, G. (2011). The costs of moving money across borders and the volume of capital flight: The case of Russia and other CIS countries. Review of world economics, 147(4), 717744.

Brada, J. C., Kutan, A. M., \& Vukšić, G. (2013). Capital flight in the presence of domestic borrowing: Evidence from Eastern European economies. World development, 51, 32-46.

Carp, L. (2014). Financial globalization and capital flows volatility effects on economic growth. Procedia Economics and Finance, 15, 350-356.

Cheung, Y. W., Steinkamp, S., \& Westermann, F. (2016). China's capital flight: Pre-and post-crisis experiences. Journal of International Money and Finance, 66, 88112.

Choong, C. K., Lau, E., Liew, V. K. S., \& Puah, C. H. (2010). Does debts foster economic growth? The experience of Malaysia. African Journal of Business Management, 4(8), 1564-1575. 
De Boyrie, T. (2011). Macroeconomic determinants of capital flight: An econometric investigation. In D. R. Lessard \& J. Williamson (Eds.), Capital flight and third world debt. Washington D.C.: Institute for International Economics.

Dickey, D. A., \& Fuller, W. A. (1979). Distribution of the estimators for autoregressive time series with a unit root. Journal of the American statistical association, 74(366a), 427-431.

Efobi, U., \& Asongu, S. (2016). Terrorism and capital flight from Africa. International Economics, 148, 81-94.

Erbe, S. (1985). The flight of capital from developing countries. Intereconomics, 20(6), 268-275.

Gunter, F. R. (2017). Corruption, costs, and family: Chinese capital flight, 1984-2014. China Economic Review, $43,105-117$.

Gusarova, V. (2009). The impact of capital flight on economic growth (Unpublished M.A. Thesis). Kyiv School of Economics.

Hermes, N., Lensink, R., \& Murinde, V. (2002). Flight capital and its reversal for development financing. UNU-WIDER Discussion Paper, 99.

Hoa, D. T. T., \& Lin, J. Y. (2016). Determinants of Foreign Direct Investment in Indochina: A Holistic Approach. International Journal of Business and Applied Social Science, 2(1), 1-10.

Ifedayo, O. M., \& Olawale, O. (2015). Impacts of capital flight on economic growth in Nigeria. International Journal for Innovation Education and Research, 3(8), 12- 25.

Isola, L. A., Oluwafunke, A. I., Victor, A., \& Asaleye, A. (2016). Exchange Rate Fluctuation and the Nigeria Economic Growth. EuroEconomica, 35(2), 127-142.

Jonathan, G. (2004). Capital flight in the Nigerian oil blamed on Government. News \& Trends: Africa, 9(22), 102 - 115

King, J. (2015). The doctrine of odious debt in international law. Cambridge: Cambridge University Press.

Kolapo, F. T., \& Oke, M. O. (2012). Nigerian economic growth and capital flight determinants. Asian Journal of Business and Management Sciences, 1(11), 76-84.

Kueh, J. S. H., Puah, C. H., \& Liew, V. K. S. (2010). Macroeconomic determinants of direct investment abroad of Singapore. Engineering Economics, 25(1), $72-81$

Kunieda, T., Okada, K., \& Shibata, A. (2014). Corruption, capital account liberalization, and economic growth: Theory and evidence. International Economics, 139, 80-108.

Lan, Y., Wu, Y., \& Zhang, C. (2010). Capital flight from China: Further evidence. Journal of International Finance and Economics, 10(2), 13-31.

Lawal I. A., Babalola B. M, Otekunrin A. O., \& Adeoti J. O. (2016). External debt and economic growth: Evidence from Nigeria. Acta Universitatis Danubius Economica 12(6), 179 -194.

Lawal, A. I., Nwanji, T. I., Asaleye, A., \& Ahmed, V. (2016). Economic growth, financial development and trade openness in Nigeria: An application of the ARDL bound testing approach. Cogent Economics \& Finance, 4(1), 1-15. http://dx.doi.org/10.1080/23 322039.2016.1258810
Lawal, A. I., Somoye, R. O., \& Babajide, A. A. (2016). Impact of oil price shocks and exchange rate volatility on stock market behavior in Nigeria. Binus Business Review, 7(2), 171-177.

Liew, S. L., Mansor, S. A., \& Puah, C. H. (2016). Macroeconomic determinants of capital flight: An empirical study in Malaysia. International Business Management, 10(13), 2526-2534.

Marashdeh, H. (2005). Stock market integration in the MENA region: An application of the ARDL bounds testing approach. Department of Economics, University of Wollongong Working Paper, 05-27.

Mukhtar, A., Ahmad, M., Waheed, M., Ullah, R. K., \& Inam, H. (2014). Determinants of Foreign Direct Investment flow in developing countries. International Journal of Academic Research in Applied Science, 3(3), 26-36.

Ndikumana, L., \& Boyce, J. K. (2008). New estimates of capital flight from sub-Saharan African countries: Linkages with external borrowing and policy options. PERI Working Papers, 144.

Ndikumana, L., Boyce, J. K., \& Ndiaye, A. S. (2015): Capital flight from Africa: Measurement and drivers. In S. I. Ajayi \& L. Ndikumana (Eds.), Capital flight from Africa: Causes, effects and policy issues. Oxford: Oxford University Press.

Odhiambo, N. M. (2010). Finance-investment-growth nexus in South Africa: An ARDL-bounds testing procedure. Economic Change and Restructuring, 43(3), 205-219.

Ozturk, I., \& Acaravci, A. (2010). The causal relationship between energy consumption and GDP in Albania, Bulgaria, Hungary and Romania: Evidence from ARDL bound testing approach. Applied Energy, 87(6), 1938-1943.

Pastor, M. (1989). Capital flight and the Latin American debt crisis. Washington D.C.: Economic Policy Institute.

Pastor, M. (1990). Capital flight from latin America. World development, 18(1), 1-18.

Pyun, J. H., \& An, J. (2016). Capital and credit market integration and real economic contagion during the global financial crisis. Journal of International Money and Finance, 67, 172-193.

Umoru, D. (2013). Capital flight and the Nigerian economy. European Journal of Business and Management, 5(4), 40-50.

Usman, F. R., \& Arene, C. J. (2014). Effects of capital flight and its macroeconomic determinants on agricultural growth in Nigeria (1970-2013). International Journal of Food and Agricultural Economics, 2(4), 107-126.

Vanguard. (2010). Nigeria: Capital flight. Retrieved from http://www.vanguardngr.com/2010/04/capital-flight/

World Bank Statistical Bulletin. (2014). Annual reports. Retrieved from https://openknowledge.worldbank. org/handle/10986/2127

Yalta, A. Y., \& Yalta, A. T. (2012). Does financial liberalization decrease capital flight? A panel causality analysis. International Review of Economics \& Finance, 22(1), 92-100. 